\title{
Screening of five Sri Lankan endemic plants for anti-cancer effects on breast cancer stem cells isolated from MCF-7 and MDA-MB-231 cell lines
}

\author{
Umapriyatharshini Rajagopalan ${ }^{1}$, Sameera $\mathbf{R}$ Samarakoon $^{1 \star}$, Kamani $\mathbf{H}$ \\ Tennekoon ${ }^{1}$, Neelika Malavige ${ }^{2}$, ED de Silva ${ }^{1}$ \\ ${ }^{1}$ Institute of Biochemistry, Molecular Biology and Biotechnology, University of Colombo, 90, Cumaratunga Munidasa Mawatha, \\ Colombo 00300, ${ }^{2}$ Department of Microbiology, Faculty of Medical Sciences, University of Sri Jayewardenepura, Gangodawila, \\ Nugegoda, Sri Lanka
}

${ }^{*}$ For correspondence: Email: sam@ibmbb.cmb.ac.lk; Tel: +94 772988414

Sent for review: 4 April 2018

Revised accepted: 23 August 2018

\begin{abstract}
Purpose: To screen selected endemic plants grown in Sri Lanka on breast cancer stem cells (bCSCs) for their anti-cancer properties

Methods: Breast-CSCs expressing CD24/CD44 surface markers were isolated from MDA-MB-231 cells by magnetic-assisted cell sorting method and validated using flow cytometry. A panel of forty extracts from barks and leaves of Doona nervosa, Garcinia quaesita, Garcinia zeylanica, Memecylon rostratum and Schumacheria castaneifolia were obtained by sequential solvent extraction and tested on bCSC-mammospheres derived from MDA-MB-231 and MCF-7 cells and normal mammary epithelial (MCF-10A) cells. Proliferation and cell stemness were analyzed using WST-1 cell proliferation assay and alkaline phosphatase assay.

Results: Hexane and chloroform extracts of G. zeylanica and G. quaesita barks showed dosedependent reduction in proliferation and stemness in both bCSCs tested with less effect on MCF-10A cells. Hexane, chloroform and ethyl acetate extracts of $S$. castaneifolia bark selectively inhibited mammospheres of triple negative bCSCs cells.

Conclusion: This study demonstrates that the non-polar extracts of G. zeylanica and G. quaesita, $S$. castaneifolia barks inhibit the proliferation of bCSCs of triple negative and estrogen-progesterone positive breast cancers. Findings of the present study may useful for developing a future anti-cancer therapeutics which can target bCSCs.
\end{abstract}

Keywords: Cancer stem cells, Garcinia zeylanica, Garcinia quaesita, Schumacheria castaneifolia, Mammospheres

\begin{abstract}
This is an Open Access article that uses a funding model which does not charge readers or their institutions for access and distributed under the terms of the Creative Commons Attribution License (http://creativecommons.org/licenses/by/4.0) and the Budapest Open Access Initiative (http://www.budapestopenaccessinitiative.org/read), which permit unrestricted use, distribution, and reproduction in any medium, provided the original work is properly credited.

Tropical Journal of Pharmaceutical Research is indexed by Science Citation Index (SciSearch), Scopus, International Pharmaceutical Abstract, Chemical Abstracts, Embase, Index Copernicus, EBSCO, African Index Medicus, JournalSeek, Journal Citation Reports/Science Edition, Directory of Open Access Journals (DOAJ), African Journal Online, Bioline International, Open-J-Gate and Pharmacy Abstracts
\end{abstract}

\section{INTRODUCTION}

Cancer stem cells (CSCs) are a small fraction of cells that exists among functionally heterogeneous cell population of a tumour. CSCs also contain progenitor/stem cell like properties $[1,2]$. They are responsible for tumour initiation, progression and contribute to the clonal 
expansion of terminally differentiated and fast cycling neoplastic cells [2]. CSCs undergo asymmetric cell division to self-renew and maintain their un-differentiated population [3].

Conventional cancer therapies such as chemotherapy and radiotherapy reduce the size of tumours by killing the differentiated phenotypes but leave the CSCs untouched [4,5]. This would proportionately increase the active CSCs in a tumour to form aggressive neoplasia. Therefore CSCs-targeted therapy should be a main part of all cancer therapies.

High overall mortality rate among breast cancer patients may be mainly due to the presence of therapy resistant types of breast cancers [6]. Triple negative breast cancer (TNBC) do not have molecular markers for estrogen receptor (ER-), progesterone receptor (PR-) and tyrosine kinase human epidermal growth factor-2 receptor (HER2-). Therefore TNBC is an aggressive variant, with a poorer short-term prognosis and has no available targeted therapies $[7,8]$.

Natural compounds and natural product pharmacophores are already in use for anticancer therapies and well known for their curative powers and unexplainable benefits in treating cancers with lesser unpleasant toxicity and organ damages compared to synthetic drugs and radiation [9]. Drugs or lead molecules derived from plants could have unique chemical moieties to modulate vital signaling pathways involved in the maintenance of CSCs [10]. Such compounds have been investigated for their efficacy to block survival, proliferation and selfrenewable pathways of CSCs in several studies conducted by other authors [11].

Sri Lanka is one of the focused hot spots for its biodiversity in tropical rainforests where endemic terrestrial evergreen plant is recorded to be approximately $70 \%$ [12]. However the potential use of Sri Lankan endemic plants in eliminating bCSCs has not been experimentally investigated. Therefore in the present study we have tested five Sri Lankan endemic plants for their anticancer stem cell activities on bCSCs expressing $\mathrm{CD} 24^{-} / \mathrm{CD} 44^{+}$surface markers isolated from MDA-MB-231; a TNBC cell line and MCF-7; luminal - A subtype breast cancer cell line in vitro.

\section{EXPERIMENTAL}

\section{Chemicals and reagents}

Enriched bCSCs of MCF-7 cell line and cancer stem premium medium were purchased from
ProMab Biotechnologies, Inc CA, USA. Dulbecco's modified Eagle's medium (DMEM), Lglutamine, trypsin-EDTA (ethylenediaminetetraacetic acid), Accutase ${ }^{\circledR}$ solution, paraformaldehyde and Triton X-100 were purchased from Sigma-Aldrich, USA. Leibovitz's medium (L15), fetal bovine serum (FBS), human recombinant insulin, penicillin-streptomycinamphotericin (PSA) and DMSO were purchased from American Type Culture Collection (ATCC), Manassas, USA. MEGM medium, epidermal growth factor (rhEGF), bovine pituitary extract (BPE), hydrocortisone, insulin, gentamicin sulfate, amphoterician-B (GA-100) were purchased from Lonza, Walkersville, MD, USA. WST-1 and alkaline phosphatase assay kits, primary and secondary antibodies were purchased from Abcam, Cambridge, MA, USA. Micro-beads conjugated to mouse monoclonal antibodies, bovine reagents and buffers for CSC isolation were obtained from Miltenyi Biotech $\mathrm{GmbH}$ - Germany. Organic solvents were obtained from Dae-Jung Chemical \& Metal Co., Ltd, Korea.

\section{Plant materials}

All plants used in the present study were selected based on the previous scientific and traditional knowledge related to their anti-cancer properties [13]. The plant materials were collected from different locations of the wet zone region of Sri Lanka in April 2015. Leaves and barks of Doona nervosa Thwaites (Family Dipterocarpaceae), Garcinia quaesita Pierre, Garcinia zeylanica Roxb. (Family - Clusiaceae), Memecylon rostratum Thwaites. (Family Melastomataceae), and Schumacheria castaneifolia Vahl (Family - Dilleniaceae) were separately collected. All plant specimens were authenticated by the Botanist, N P T Gunawardena at the National Herbarium, Department of National Botanic Gardens, Royal Botanic Gardens, Peradeniya, Sri Lanka and deposited as herbarium specimens (no. $6 / 01 / \mathrm{H} / 03-1,2,3,4$ and 5).

\section{Preparation of plant extracts}

Dried materials were pulverized to fine powder and $5 \mathrm{~g}$ from each plant bark and leaves were exhaustively extracted with four different solvents namely hexane, chloroform, ethyl acetate and methanol. The sequential extraction process was augmented by ultra-sonication while maintaining the temperature within $25-40{ }^{\circ} \mathrm{C}$. Residual solvents were evaporated from yielded extracts under reduced pressure and stored at $-20^{\circ} \mathrm{C}$ until use. Stock solution of each extract was prepared by dissolving the dried extracts with 
$100 \%$ dimethyl sulfoxide (DMSO) and sterilized by passing through $0.22 \mu \mathrm{m}$ membrane filters.

\section{Cell culture}

Human breast metastatic cancer cell line, MDAMB-231 (triple negative) was cultured and maintained as monolayer culture in $\mathrm{L}-15$ medium supplemented with $10 \%(\mathrm{v} / \mathrm{v})$ heat inactivated FBS, $10 \mu \mathrm{g} / \mathrm{mL}$ human recombinant insulin, $1 \%$ PSA, $2 \mathrm{mM}$ L-glutamine at $37^{\circ} \mathrm{C}$ without $\mathrm{CO}_{2}$. MCF-10A (normal mammary epithelial) cell line was cultured in total MEGM growth medium at 37 ${ }^{\circ} \mathrm{C}$ in humidified $5 \% \mathrm{CO}_{2}$ atmosphere.

\section{Isolation of bCSCs from MDA-MB-231 cell line by MACS}

MDA-MB-231 cells were harvested using $0.25 \%$ $(\mathrm{v} / \mathrm{v})$ trypsin in $0.61 \%(\mathrm{w} / \mathrm{v})$ EDTA solution and washed with phosphate-buffered saline (PBS) (137 mM NaCl, $2.7 \mathrm{mM} \mathrm{KCl}, 10 \mathrm{mM} \mathrm{Na} 2 \mathrm{HPO}_{4}$ and $2 \mathrm{mM} \mathrm{KH}_{2} \mathrm{PO}_{4}, \mathrm{pH} 7.4$ ) to isolate $\mathrm{CD} 24^{-}$ /CD44 ${ }^{+}$bCSCs like cells using magnetic assisted cell sorting technique (MACS). Briefly, the cell suspension was centrifuged at $300 \mathrm{~g}$ for $10 \mathrm{~min}$ and re-suspended in autoMACS ${ }^{\mathrm{TM}}$ running buffer (0.5\% BSA and 2 mM EDTA in PBS, pH 7.2). Then, $10 \mu \mathrm{L}$ of human CD24 antibody conjugated with biotin was added into the cell suspension $\left(1 \times 10^{7}\right.$ cells $\left./ 40 \mu \mathrm{L}\right)$ and incubated at 2 - $8^{\circ} \mathrm{C}$ in the dark for $15 \mathrm{~min}$.

After incubation, cell suspension was washed with running buffer and labelled with $20 \mu \mathrm{L}$ of anti-biotin micro-beads at $2-8{ }^{\circ} \mathrm{C}$ for $15 \mathrm{~min}$ in the dark. The cell suspension was centrifuged and the pellet obtained was re-suspended in fresh running buffer and eluted through MACS $\AA$ LD (depletion) column to collect unlabeled cells (CD24) These cells were labeled with CD44 micro-beads $\left(20 \mu \mathrm{L} / 1 \times 10^{7}\right.$ cells in $80 \mu \mathrm{L}$ running buffer) and incubated at $2-8{ }^{\circ} \mathrm{C}$ in the dark for 15 min. Finally the cells were passed through MACS $\AA$ LS (positive selection) column and cells bound to the magnetic beads were eluted with running buffer and then detached from the magnetic separator. The yielded CD24/CD44 cell population was collected by centrifugation.

\section{Mammosphere culture from isolated CD24 $/ \mathrm{CD}^{+} 4^{+}$cell population}

The CD24/CD $44^{+}$cell population isolated from MDA-MB-231 cells and commercially available bCSCs of MCF-7 cells were suspended in serum-free cancer stem premium medium in ultra-low attachment 6-well plates for 7 - 10 days to produce mammospheres. About $10 \%$ of fresh media were used to replenish the culture every other day throughout the culture period. The tumorspheres were visualized under inverted phase contrast light microscope (Olympus CKX41SF, Olympus Co-operation, Tokyo, Japan). Prolonged mammosphere cultures were maintained to enrich bCSCs and sub-passaged by dissociating the mammospheres into single cells using $500 \mu \mathrm{L}$ of $1 \mathrm{X}$ Accutase.

\section{Validation of isolated bCSCs by flow cytometry}

Ten days old mammospheres of bCSCs isolated from MDA-MB-231 cells were collected by centrifugation (800 g, $2 \mathrm{~min}$ ), washed with PBS and dissociated using 1X Accutase. Collected cells were re-suspended in PBS and fixed with paraformaldehyde and permeabilised with $0.5 \%$ Triton X-100.

Cells were incubated with rabbit polyclonal antiCD44 primary antibody (Abcam, clone ab157107, at $1: 100$ ) for $30 \mathrm{~min}$ at $4^{\circ} \mathrm{C}$ and then with APC conjugated goat anti-rabbit secondary antibody (Abcam, clone ab130805, at 1:200) for 30 min in the dark at $22^{\circ} \mathrm{C}$ with gentle agitation. Similarly cells were incubated with anti-CD24 antibody (Abcam, clone ab76514, at 1:1000). Then cells were incubated with secondary antibody goat anti-mouse IgG H\&L (Abcam, clone ab7064, 1:1000) conjugated with FITC fluorophore in same concentrations according to the manufacturer's instruction. In each step, cells were washed twice with ice-cold PBS and collected by centrifugation before analyzed using flow cytometry. Cells were acquired on a Partec Cyflow Cube 6 flow cytometer and analyzed with De Novo FCS Express software version 4.

\section{Evaluation of anti-proliferative effects of plant extracts}

Different concentrations $(25,50,100,200$ and $400 \mu \mathrm{g} / \mathrm{mL}$ ) of the forty crude extracts of bark and leaves of the five selected plants were tested for anti-proliferative effects on 4-days old bCSC mammospheres of MCF-7 and MDA-MB-231 cells, using WST-1 cell viability assay at $24 \mathrm{~h}$ post incubation as described by de la Mare et al [14]. Assay readings were recorded at $440 \mathrm{~nm}$ with reference at $650 \mathrm{~nm}$ using Synergy ${ }^{\mathrm{TM}}$ multimode microplate reader (BioTek, Winooski, USA). All experiments were carried out in quintuplicate.

Similarly, anti-proliferative effects of all plant extracts were tested on normal mammary epithelial (MCF-10A) cells $\left(5 \times 10^{3}\right.$ cells/well) using WST-1 assay at $24 \mathrm{~h}$ post treatment. 


\section{Alkaline phosphatase assay}

Breast CSCs of MCF-7 and MDA-MB-231 cells were seeded at a density of $5 \times 10^{3} \mathrm{cells} /$ well of 96-well ultralow attachment plate in $100 \mu \mathrm{L}$ of cancer premium medium and allowed to form mammospheres. Mammospheres were treated on the $4^{\text {th }}$ day with selected active plant extracts and alkaline phosphatase activity assay was performed $24 \mathrm{~h}$ after treatment using ALP assay kit according to the manufacturer's protocol (Abcam, Cambridge, USA). Treated and untreated bCSC-mammospheres were washed with PBS and cellular alkaline phosphatase was extracted using extraction buffer. Cell suspensions were centrifuged for $3 \mathrm{~min}$, at 13 , $000 \mathrm{~g}$ and supernatants containing ALP enzyme were transferred into new vials. The supernatants were allowed to react with excess amount of $5 \mathrm{mM}$ non-fluorescent 4methylumbelliferyl phosphate disodium salt (MUP) substrate for $1 \mathrm{~h}$ at room temperature, which yielded a fluorescent product, 4methylumbelliferone (4-MU) (Ex/Em $=360$ $\mathrm{nm} / 440 \mathrm{~nm}$ ) in the presence of ALP. A calibration curve was drawn for standard concentrations of substrate versus ALP enzymes.

\section{Statistical analysis}

All data are presented as mean \pm standard deviation (SD). Statistical significance and half maximal inhibitory concentration $\left(\mathrm{IC}_{50}\right)$ values were determined using GraphPad Prism software (San Diego, California). One-way analysis of variance (ANOVA) with Dunnett post-test was used to compare all treatment concentrations with control, and $p<0.05$ was considered to indicate a statistically significant difference in ALP activity test.

\section{RESULTS}

\section{Isolation of $C D 24^{-} / C D 44^{+}$cells and enrichment of bCSCs from MDA-MB-231 cell line}

Isolated bCSCs from MDA-MB-231 cells by MACS method were grown on in vitro ultralow attachment culture flasks over a couple of weeks. As shown in Figure 1, the percentile dot-plot of flow cytometry analysis demonstrated the presence of four distinct epithelial cell populations; $\quad \mathrm{CD} 24^{-} / \mathrm{CD} 44^{-}, \quad \mathrm{CD} 24^{-} / \mathrm{CD}_{4} 4^{+}$, $\mathrm{CD}^{2} 4^{+} / \mathrm{CD} 44^{-}$and $\mathrm{CD} 24^{+} / \mathrm{CD} 44^{+}$in $7.08,92.20$, 0.09 and $0.63 \%$, respectively in the isolated bCSCs from MDA-MB-231 cells.

During mammosphere development it were observed as shown in Figure 2, the two different types of mammospheres are produced from
bCSCs obtained from MDA-MB-231 and MCF-7 cell lines. They showed morphologically different sphere like masses.

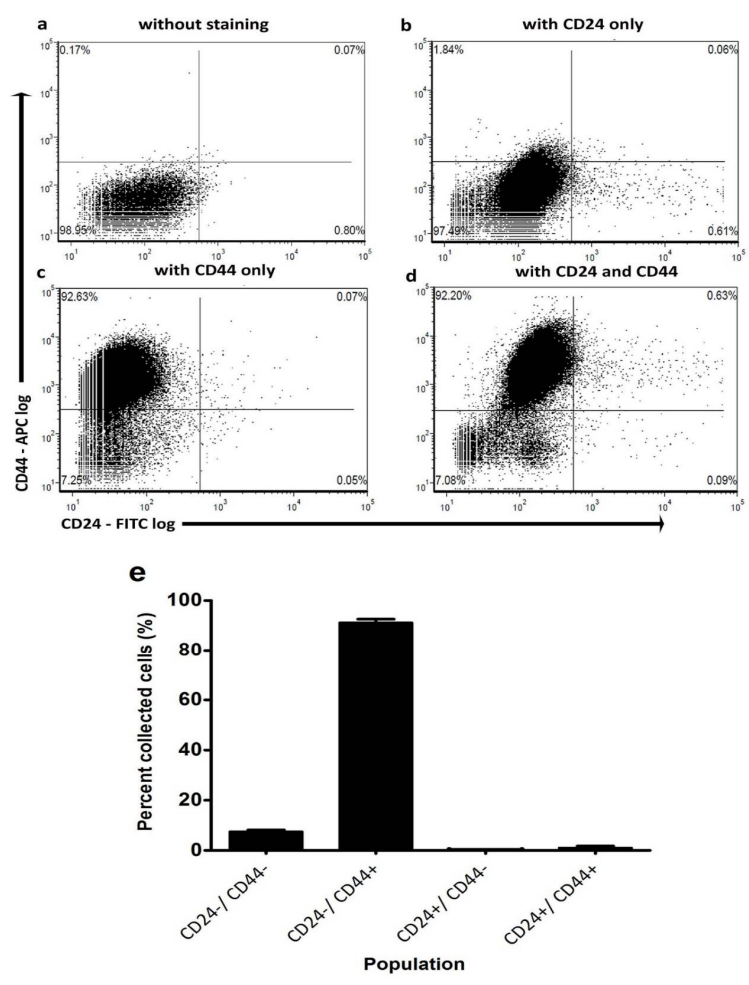

Figure 1: Flow cytometry results for isolated bCSCs from MDA-MB-231 cells. (a) Unstained control. (b) Cells stained with CD24-FITC only. (c) bCSCs stained with CD44-APC only. (d) bCSCs dually stained with both CD24-FITC and CD44-APC. (e) Illustrate different population present in the bCSC-enriched culture and $\mathrm{CD} 44^{+/ \text {high }} \mathrm{CD} 24^{-/ \text {low }}$ is the majority among the cell population

\section{Anti-proliferative effects of plant extracts on bCSC-mammospheres}

The extracts with $\mathrm{IC}_{50}<50 \mu \mathrm{g} / \mathrm{mL}$ were considered as active extracts. As indicated in Table 1 , a total of $10(25 \%)$ extracts showed potent anti-proliferative effects on bCSCs with $\mathrm{IC}_{50}$ values less than $50 \mu \mathrm{g} / \mathrm{mL}$.

\section{Effects of plant extracts on stem cell marker alkaline phosphatase in bCSCs}

Cellular ALP enzyme activity was measured by a sensitive fluorometric method in order to analyze the effects of most active plant extracts on the stemness of bCSCs grown as mammospheres at $24 \mathrm{~h}$ post treatment. All the active bark extracts tested in the present study remarkably reduced the ALP activity of both bCSC-mammospheres than their counterpart leaf extracts in general as indicated in Figure 3 and Figure 4. 


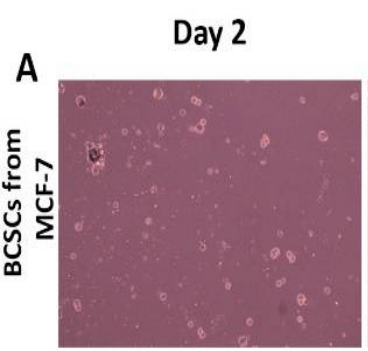

Day 4

B

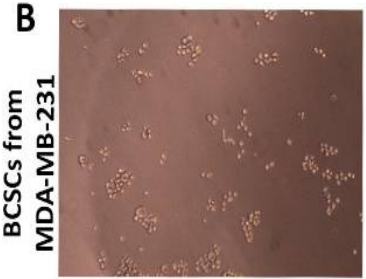

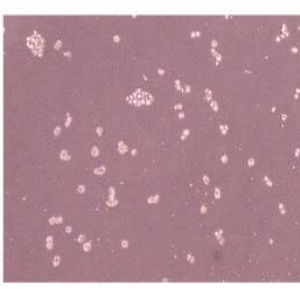

Day 6
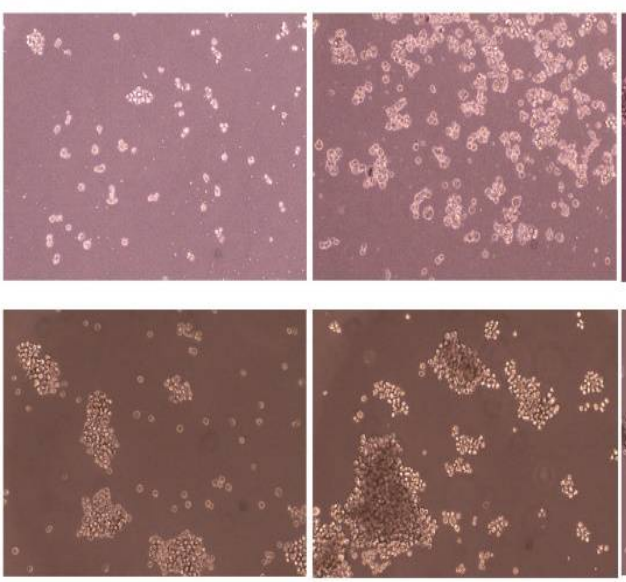

Day 10

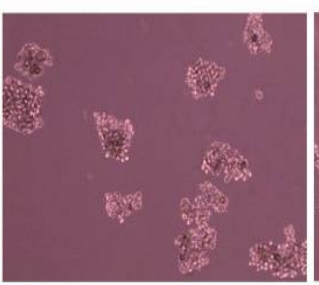

Day 14
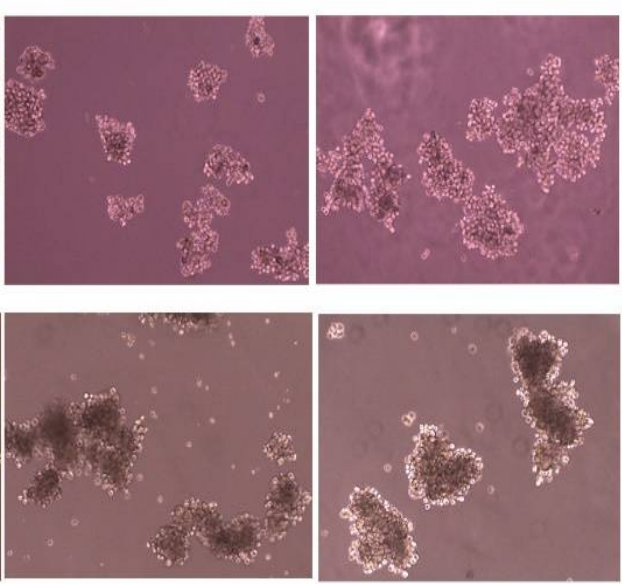

Figure 2: Morphological observations captured under a phase contrast light microscopy at 100x magnification of different development stages of mammospheres derived from bCSCs cells. (A) Mammospheres from bCSCs enriched cultures derived from MCF-7 cells. (B) bCSCs isolated from MDA-MB-231 cells

Table 1: Anti-proliferative effect $\left(\mathrm{IC}_{50}, \mu \mathrm{g} / \mathrm{mL}\right)$ of extracts of five Sri Lankan endemic plants on bCSCs isolated from MCF-7 and MDA-MB-231 cell lines and MCF-10A normal mammary epithelial cells. Anti-proliferative effects of plant extracts were evaluated based on $\mathrm{IC}_{50}$ values estimated by WST-1 cell proliferation assay at $24 \mathrm{~h}$ posttreatment

\begin{tabular}{|c|c|c|c|c|c|c|c|}
\hline \multirow[b]{2}{*}{ Type of cells } & \multirow{2}{*}{\multicolumn{2}{|c|}{ Extract }} & \multicolumn{5}{|c|}{ Plant } \\
\hline & & & $\begin{array}{c}\text { Memecylon } \\
\text { rostratum }\end{array}$ & $\begin{array}{c}\text { Schumacheria } \\
\text { castaneifolia }\end{array}$ & $\begin{array}{c}\text { Garcinia } \\
\text { zeylanica }\end{array}$ & $\begin{array}{l}\text { Garcinia } \\
\text { quaesita }\end{array}$ & $\begin{array}{c}\text { Doona } \\
\text { nervosa }\end{array}$ \\
\hline $\begin{array}{l}\text { BCSC-enriched } \\
\text { mammospheres } \\
\text { from MCF-7 cell } \\
\text { line }\end{array}$ & Bark & $\begin{array}{l}\text { n-Hexane } \\
\mathrm{CHCl}_{3} \\
\mathrm{EtOAc} \\
\mathrm{MeOH} \\
\text { n-Hexane } \\
\mathrm{CHCl}_{3} \\
\mathrm{EtOAc} \\
\mathrm{MeOH}\end{array}$ & $\begin{array}{c}34.77 \\
62.87 \\
102 \\
194.2 \\
558.5 \\
>1000 \\
42.97 \\
>1000\end{array}$ & $\begin{array}{c}729.9 \\
>1000 \\
125.9 \\
401 \\
>1000 \\
>1000 \\
>1000 \\
931\end{array}$ & $\begin{array}{l}13.65 \\
5.117 \\
>1000 \\
133.4 \\
>1000 \\
>1000 \\
>1000 \\
>1000\end{array}$ & $\begin{array}{c}38.79 \\
48.28 \\
235.6 \\
382 \\
>1000 \\
>1000 \\
263.3 \\
>1000\end{array}$ & $\begin{array}{c}63.24 \\
148.7 \\
813.9 \\
266.4 \\
70.75 \\
239.9 \\
>1000 \\
390\end{array}$ \\
\hline $\begin{array}{l}\text { BCSC-enriched } \\
\text { mammospheres } \\
\text { from MDA-MB- } \\
231 \text { cell line }\end{array}$ & Leaf & $\begin{array}{l}\text { n-Hexane } \\
\mathrm{CHCl}_{3} \\
\mathrm{EtOAc} \\
\mathrm{MeOH} \\
\text { n-Hexane } \\
\mathrm{CHCl}_{3} \\
\mathrm{EtOAc} \\
\mathrm{MeOH}\end{array}$ & $\begin{array}{l}309.6 \\
743.4 \\
>1000 \\
>1000 \\
>1000 \\
199.4 \\
>1000 \\
752.1\end{array}$ & $\begin{array}{l}54.22 \\
37.20 \\
35.42 \\
329.6 \\
216.7 \\
206.3 \\
207.9 \\
359.7\end{array}$ & $\begin{array}{c}0.417 \\
1.774 \\
14.80 \\
54.81 \\
>1000 \\
83.21 \\
891.5 \\
>1000\end{array}$ & $\begin{array}{c}17.73 \\
59.62 \\
>1000 \\
>1000 \\
412.8 \\
116.7 \\
191.4 \\
199.9\end{array}$ & $\begin{array}{l}149.1 \\
24.48 \\
458.4 \\
529.4 \\
364.7 \\
153.8 \\
346.0 \\
252.7\end{array}$ \\
\hline $\begin{array}{l}\text { MCF-10A normal } \\
\text { breast epithelial } \\
\text { cells }\end{array}$ & $\begin{array}{l}\text { Bark } \\
\text { Leaf }\end{array}$ & $\begin{array}{l}\text { n-Hexane } \\
\mathrm{CHCl}_{3} \\
\mathrm{EtOAc} \\
\mathrm{MeOH} \\
\text { n-Hexane } \\
\mathrm{CHCl}_{3} \\
\mathrm{EtOAc} \\
\mathrm{MeOH}\end{array}$ & $\begin{array}{l}397.8 \\
>1000 \\
>1000 \\
>1000 \\
>1000 \\
901.6 \\
>1000 \\
>1000\end{array}$ & $\begin{array}{l}>1000 \\
>1000 \\
>1000 \\
>1000 \\
>1000 \\
573.0 \\
>1000 \\
>1000\end{array}$ & $\begin{array}{r}39.65 \\
15.42 \\
271.4 \\
104.9 \\
>1000 \\
805.0 \\
>1000 \\
960.7\end{array}$ & $\begin{array}{l}351.5 \\
>1000 \\
>1000 \\
>1000 \\
>1000 \\
691.1 \\
>1000 \\
>1000\end{array}$ & $\begin{array}{l}>1000 \\
720.4 \\
>1000 \\
>1000 \\
594.6 \\
>1000 \\
>1000 \\
>1000\end{array}$ \\
\hline
\end{tabular}

\section{DISCUSSION}

This study revealed that the bCSCs isolated from MDA-MB-231 cell line by MACS method using CD44 and CD24 antibodies consist significant amount of $\mathrm{CD} 24^{- \text {/low }} \mathrm{CD} 44^{+ \text {/high }}$ cell population $(92.20 \%)$. Zhang et al. have also isolated bCSCs from MDA-MB-231 and MCF-7 cell lines by MACS method using CD44, CD24 and CD326 antibodies and obtained $\mathrm{CD} 24^{-} / \mathrm{CD} 44^{+}$cell populations similar to the observations in the present study $[15,16]$. Further, the flow cytometry results validated the efficacy of MACS method for the isolation of bCSCs in vitro. In the present study, mammospheres produced from estrogen receptor positive cells (MCF-7) showed clear 


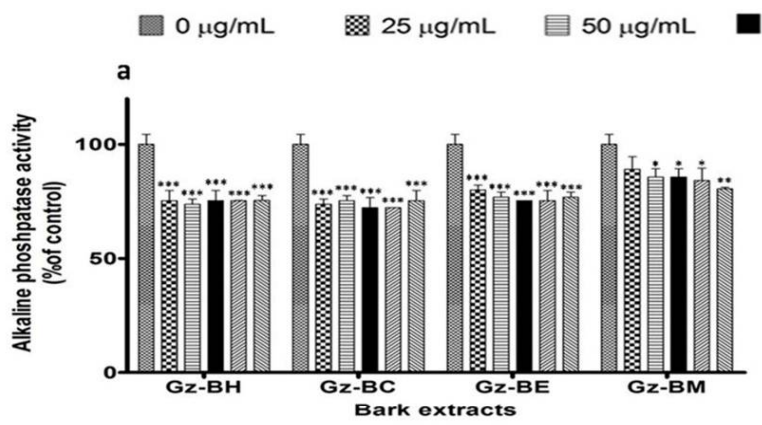

$100 \mu \mathrm{g} / \mathrm{mL} \square 200 \mu \mathrm{g} / \mathrm{mL} \square 400 \mu \mathrm{g} / \mathrm{mL}$
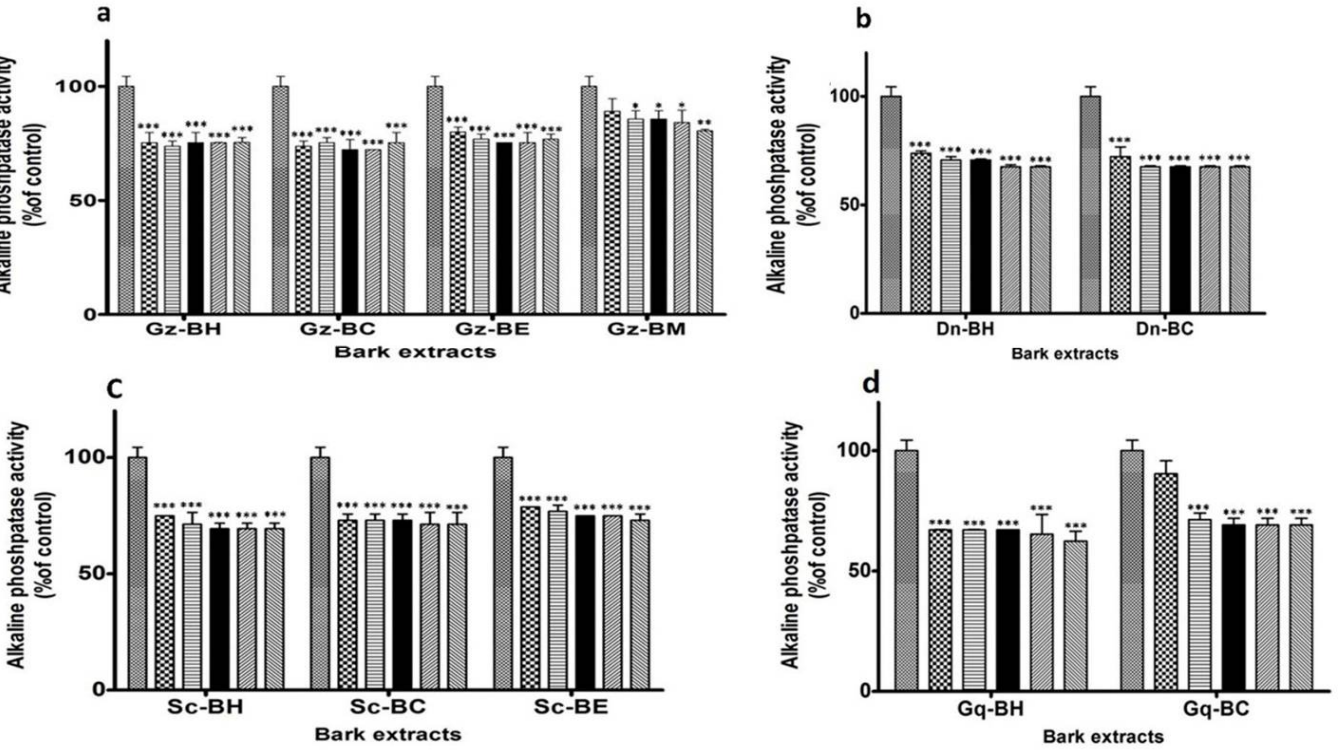

Figure 3: Effects of plant bark extracts on cellular alkaline phosphatase activity of bCSCs derived from MDA-MB231 cells. (A) Percentile ALP activity was measured with various concentrations of active extracts after $24 \mathrm{~h}$ exposure. Only active bark extracts were tested. Plant extracts were illustrated in the graphs according to given codes of the sample: (a) Gz - G. zeylanica, (b) Dn - D. nervosa, (c) Sc - S. castaneifolia, (d) Gq - G. quaesita and $\mathrm{Mr}$ - M. rostratum; B - bark, L - leaf, H - n-hexane extract, C - chloroform extract, E - ethyl acetate extract and M methanol extract. Results are expressed as mean \pm standard deviation of triplicate determinations; ${ }^{* * *} p<0.001$, ${ }^{* *} p=0.001$ to 0.01 and ${ }^{*} p=0.01$ to 0.05 compared with control
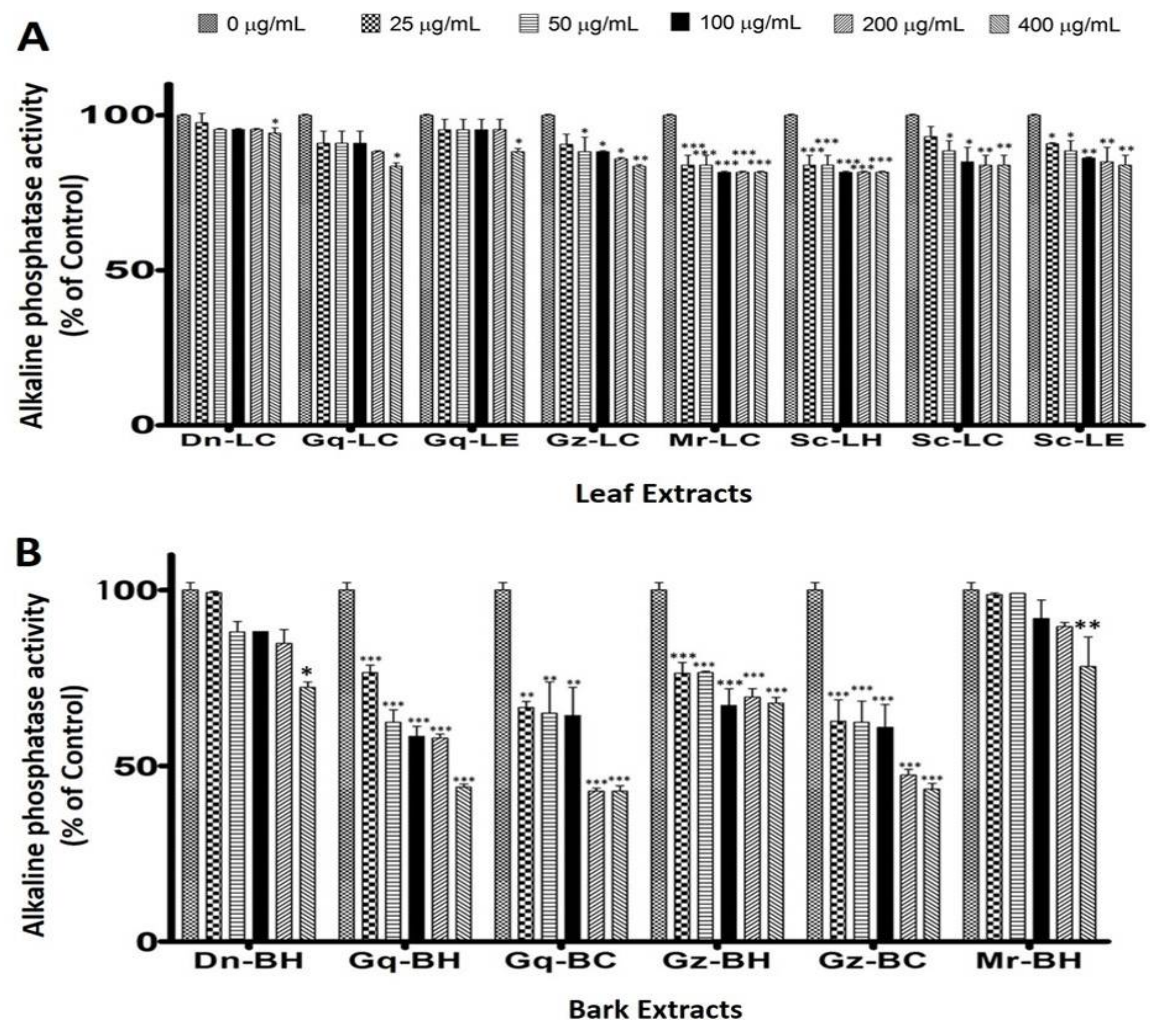

Figure 4: Effect of plant extracts on cellular alkaline phosphatase activity of bCSCs. Percentile ALP activity was measured with active (A) leaf extracts in bCSCs derived from MDA-MB-231 cells after $24 \mathrm{~h}$ exposure with various concentrations. Only active (B) bark extracts were tested on bCSCs of MCF-7 cells and no leaf extracts were studied as they are not active in those cells. Plant extracts were illustrated in the graphs as same as Figure 3. Results are expressed as mean \pm standard deviation of triplicate determinations; ${ }^{* *} p<0.001,{ }^{* *} p=0.001$ to 0.01 and ${ }^{*} p=0.01$ to 0.05 compared with control. 
round, tightly cohesive structures displaying robust cell-cell adhesion under phase contrast microscopy as described by other authors [17].

In the present study, the effect of forty plant extracts on cell proliferation and stemness of bCSCs was assessed by evaluating cell viability and alkaline phosphatase activity respectively. Effective elimination of chemotherapy and radiotherapy resistant CSC population is a requirement for any promising drug candidate that targets CSCs. Alkaline phosphatase (ALP), is used as a putative stem cell marker to characterize the pluripotency of CSCs [18].

Hexane and chloroform extracts of G. zeylanica bark showed a higher anti-proliferative effect than positive control paclitaxel on both bCSCs with $\mathrm{IC}_{50}<15 \mu \mathrm{g} / \mathrm{mL}$, whereas ALP enzyme activity was reduced by $>25 \%$. A similar pattern was shown by the hexane and chloroform extracts of $G$. quaesita bark on both bCSCs $\left(\mathrm{IC}_{50}\right.$ : 18 - $\left.49 \mu \mathrm{g} / \mathrm{mL}\right)$. Hexane and chloroform extracts of $G$. quaesita bark did not exert any anti-proliferative effect on normal mammary epithelial cells. Hexane extract exerted a greater suppression of ALP activity than the chloroform extract $(32.7 \%$ vs $10 \%$ at the lowest concentration of $25 \mu \mathrm{g} / \mathrm{mL}$ used).

Among the active bark extracts, five extracts from M. rostratum, G. quaesita and G. zeylanica displayed considerable anti-proliferative activity against bCSCs from ER+ breast cancer (MCF-7) and seven extracts from $G$. quaesita, $G$. zeylanica, $S$. castaneifolia and $D$. nervosa reduced the growth of mammospheres of MDAMB-231 cell line in concentration dependent manner. The two plants from the same family Garcinia (G. quaesita and G. zeylanica) wielded steady and extensive anti-proliferative effects on both the bCSCs tested in the present study. Cytotoxic effects of chloroform, ethyl acetate and methanol extracts of $S$. castaneifolia bark on MDA-MB-231 cells had been reported by Jayarathna et al [13].

Also, hexane extract of $M$. rostratum bark and ethyl acetate extract of $M$. rostratum leaves had been reported for their cytotoxicity on MCF-7 cells in the same study. Even though several other plants from Garcinia family have been investigated for their anti-cancer effects on different carcinoma cell lines $[19,20]$, there were no previous studies that have been carried out on the anti-proliferative effect of the above two plants on bCSCs. Besides, hexane extract of $M$. rostratum bark and chloroform extract of $D$. nervosa bark also reduced cell proliferation of bCSCs of MCF-7 and MDA-MB-231 cells respectively (with $\mathrm{IC}_{50}: 34.77$ and $24.48 \mu \mathrm{g} / \mathrm{mL}$, respectively) while leaving no effect on MCF-10A cells.

The Sri Lankan endemic plants used in the present study have not yet been studied for their anti-proliferative properties on breast CSCs. However, in the present study we have tested anti proliferative effects of these plants extracts at a single incubation time interval since the main aim of this study is to screen selected plant on bCSCs. Therefore, active compounds need to be isolated from these extracts and tested at different time intervals. Even though there are many natural products available for cancer treatment, only a few compounds such as salinomycine, parthenolide, epigallocatechin gallate, curcumin, etc have successfully passed the in vitro studies for their efficacy in targeting CSCs. However clinical studies on these compounds have not yet been completed [10]. Therefore, the results of the present study can be used to search for novel anti-cancer compounds that can kill bCSCs.

\section{CONCLUSION}

The findings of the present study demonstrate that bark extracts of $G$. zeylanica, G. quaesita and $S$. castaneifolia inhibit the proliferation of bCSCs in vitro. This is the first study to report the anti-cancer activity of the selected Sri Lankan endemic plants ( $G$. zeylanica, G. quaesita and $S$. castaneifolia) on breast cancer stem cells. Further studies are necessary to elucidate the mechanism of action of the anti-cancer stem cell activity of these plants and their isolated active compounds.

\section{DECLARATIONS}

\section{Acknowledgement}

This work was supported by Nation Research Council, Colombo, Sri Lanka (NRC - 14 - 067). We thank Dr Achala Kamaladasa, Department of Microbiology, Faculty of Medical Sciences, University of Sri Jayawardenapura, Sri Lanka for assisting in flow cytometry experiments.

\section{Conflict of interest}

The authors declare that they have no competing interests with regard to this work.

\section{Authors' contributions}

We declare that this work was done by the authors named in this article and all liabilities 
pertaining to claims relating to the content of this article will be borne by the authors. This work was done by collaboration between all authors. SRS designed the experiment, supervised the study and revised the manuscript. UR performed all the experiments, data analysis and drafted the manuscript. KHT supervised the study and revised the manuscript. GNM and EDS revised the manuscript. All authors read and approved the final manuscript.

\section{REFERENCES}

1. Pattabiraman DR, Weinberg RA. Tackling the cancer stem cells-what challenges do they pose?. Nat Rev Drug Discov 2014; 13(7): 497-512.

2. Kreso A, Dick JE. Evolution of the cancer stem cell model. Cell Stem Cell 2014; 14: 275-291.

3. Brooks MD, Burness ML, Wicha MS. Therapeutic implications of cellular heterogeneity and plasticity in breast cancer. Cell Stem Cell 2015; 17(3): 260-271.

4. Pisco AO, Huang S. Non-genetic cancer cell plasticity and therapy-induced stemness in tumour relapse: What does not kill me strengthens me. Br J Cancer 2015; 112 : 1725-1732.

5. Vidal SJ, Rodriguez-Bravo V, Galsky M, Cordon-Cardo $C$, Domingo-Domenech J. Targeting cancer stem cells to suppress acquired chemotherapy resistance. Oncogene 2014; 33: 4451-4463.

6. Al-Hajj M, Wicha MS, Benito-Hernandez A, Morrison SJ, Clarke MF. Prospective identification of tumorigenic breast cancer cells. Proc Natl Acad Sci USA 2003; 100(7): 3983-3988.

7. Bauer KR, Brown M, Cress RD, Parise CA, Caggiano V. Descriptive analysis of estrogen receptor (ER)-negative, progesterone receptor (PR)-negative, and HER2negative invasive breast cancer, the so-called triplenegative phenotype: A population-based study from the California cancer registry. Cancer 2007; 109: 17211728.

8. Suba Z. Triple-negative breast cancer risk in women is defined by the defect of estrogen signaling: preventive and therapeutic implications. Onco Targets Ther 2014; 7: 147-164.

9. Clardy J, Walsh C. Lessons from natural molecules. Nature 2004; 432: 829-837.
10. Moselhy J, Srinivasan S, Ankem MK, Damodaran C. Natural products that target cancer stem cells. Anticancer Res 2015; 35(11): 5773-5788.

11. Najumudeen AK, Jaiswal $A$, Lectez $B$, Oetken-Lindholm C, Guzmán C, Siljamäki E, Posada IMD, Lacey E, Aittokallio T, Abankwa D. Cancer stem cell drugs target $K$-ras signaling in a stemness context. Oncogene 2016; 35(40): 5248-5262.

12. Gunatilleke N, Pethiyagoda R, Gunatilleke S. Biodiversity of Sri Lanka. Journal of the National Science Foundation of Sri Lanka. 2008; 36(Special Issue): 25-61.

13. Jayarathna PP, Tennekoon KH, Samarakoon SR, Thabrew I, Karunanayake EH, Silva ED de, Ediriweera MK. Cytotoxic, antioxidant and apoptotic effects of twenty Sri Lankan endemic plants in breast cancer cells. European J Med Plants 2016; 5(1): 1-15.

14. de la Mare JA, Sterrenberg JN, Sukhthankar MG, Chiwakata MT, Beukes DR, Blatch GL, Edkins AL. Assessment of potential anti-cancer stem cell activity of marine algal compounds using an in vitro mammosphere assay. Cancer Cell Int 2013; 13(1): 39.

15. Zhang H, Cai K, Wang J, Wang $X$, Cheng $K$, Shi F, Jiang L, Zhang Y, Dou J. MiR-7, inhibited indirectly by lincRNA HOTAIR, directly inhibits SETDB1 and reverses the EMT of breast cancer stem cells by downregulating the STAT3 pathway. Stem Cells 2014; 32(11): 2858-2868.

16. Kim MH, Kim MH, Kim KS, Park MJ, Jeong JH, Park SW, Ji YH, Kim KI, Lee TS, Ryu PY et al. In vivo monitoring of $C D 44+$ cancer stem-like cells by $Y$-irradiation in breast cancer. Int J Oncol 2016; 48(6): 2277-2286.

17. Holliday DL, Speirs V. Choosing the right cell line for breast cancer research. Breast cancer research. Breast Cancer Res 2011; 13(4): 215.

18. Lee E, McKean-Cowdin R, Ma H, Spicer DV, Van Den Berg $D$, Bernstein L, Ursin G. Characteristics of triplenegative breast cancer in patients with a BRCA1 mutation: Results from a population-based study of young women. J Clin Oncol 2011; 29(33): 4373-4380.

19. Farombi EO, Owoeye $O$. Antioxidative and chemopreventive properties of Vernonia amygdalina and Garcinia biflavonoid. Int J Environ Res Public Health 2011; 8: 2533-2555.

20. Aisha AFA, Abu-Salah KM, Ismail Z, Majid AMSA. In vitro and in vivo anti-colon cancer effects of Garcinia mangostana xanthones extract. BMC Complement Altern Med 2012; 12: 104. 